\title{
Developing Algebra Structure Module and Model of Cooperative Learning Helping Concept Map Media for Improving Proofing Ability
}

\author{
Syafari ${ }^{1}$ \\ ${ }^{1}$ Department of Mathematics, Science Faculty, State University of Medan, Indonesia \\ Correspondence: Syafari, Department of Mathematics, Science Faculty, State University of Medan, Indonesia. \\ E-mail: fari0929@gmail.com
}

Received: July 25, 2016

Accepted: September 2, 2016

Online Published: February 27, 2017

doi:10.5539/ies.v10n3p207

URL: https://doi.org/10.5539/ies.v10n3p207

\begin{abstract}
This research was purposed to develop module and learning model and instrument of proofing ability in algebra structure through cooperative learning with helping map concept media for students' of mathematic major and mathematics education in State University and Private University in North Sumatra province. The subject of this research was the students' of mathematic and mathematics education in Medan State University and Qualitye University. Developmental Research that oriented on developing product at stage and first year was done identification of proofing and positive behavior on algebra structure based on curriculum and was developed module and model cooperative learning with helping concept media map. The result that got at the first stage was the formula of proofing ability and positive behavior on algebra structure with first module and model cooperative learning assisting concept media map that assumed effective, efficient in algebra structure. Module and model of this learning consist of the book of lecturing guiding (lecturing unity schedule, lecturing contract, and lesson plan), module, and book of students' assignment.
\end{abstract}

Keywords: concept media map, cooperative learning, proofing ability

\section{Introduction}

Proofing is the main characteristic from mathematical activity that done from since students sat in Elementary School until in the University. This thing was said explicitly in school curriculum so that the students have mathematic competent in forming the ability of arranging prove, that is students of Elementary School and Junior High School to arrange the prove inductively, though students of Senior High School arrange the prove inductively and deductively.

Process of proofing of mathematic on grade the university the form of more formal and more accurate than by proofing in elementary school and Junior high school (Lee, 2004), that is by using deductive method, that is implication, contradiction, contraposition, or prove directly, this thing is very difficult to understand by students, it means that indicate that the ability of proofing need to be a special pay attention and to be key of process in learning. Algebra structure is one of subject need to get a special attention, to remember this subject is one of the subject that join in group/class analysis of mathematic and algebra that have pure and abstract behavior, that is one of the subject that encourage maximal proofing ability. As one of subject from pure mathematic, concepts that consist of inside it commonly are definition, axiom, and theorems that consist on hierarchy.

From the researcher's experience through taking this subject algebra structure shown that many students that feel mistake in processing the prove, for example for proofing the form of implication: if $A \subset B$ so $\mathrm{B}^{\mathrm{c}} \subset \mathrm{A}^{\mathrm{c} \text {. So }}$. many students that use $\mathrm{B}^{\mathrm{c}} \subset \mathrm{A}^{\mathrm{c}}$ for proofing the above problem, even though the form of $\mathrm{B}^{\mathrm{c}} \subset \mathrm{A}^{\mathrm{c}}$ that will be proved.

From the result of research from Muliono and Syafari (2009) also indicated that was not so far different, many students that did not understand the requirements of grouping from the association, for example $H=\{a \in G \mid a x$ $=\mathrm{x} \mathrm{a}, \forall \mathrm{x} \in \mathrm{G}\}$, it means that can be seen when it is asked what is the requirement's to be group of association of $\mathrm{H}$ ? The understanding of the concept is the most important thing in processing of proofing.

To be observed from students' ability, the concept error like the above case is very big probability because of the minimum of requirements knowledge that owned of students, the behavior of students that less of interest/motivation in learning the material, and the students often just keep silent and afraid to ask the questions, 
are not brave to explore their idea. Beside the process of old learning that use text book and presenting that less consider the grade of cognitive ability and students' real world context that causes the interaction of students is less maximal, beside evaluation that just pointed to the results and not process.

The researcher's experience when to solve the above problem try to take that problem in daily life of the students, for example $\mathrm{H}$ is the association of Senat Unimed, and $\mathrm{G}$ is association of faculty students, what are the requirements to be group of $\mathrm{H}$ association? When this question is given to the students, most of the students started to less to know about the problem.

Although for being maximal, the interaction of learning between the same students was done through cooperative approach by maximizing the role of same tutor. This thing is supported from the results of Muliono and Syafari (2009) that indicate the process of cooperative learning with assisting concept media map can improve the ability of proofing ability and interaction of students, the result of the research also recommended needed lesson material that designed based on the cognitive grade and context of real word of the students. The purpose of this research are (1) identification and analyze the instrument of proofing ability of the students and formulate in logic range and systematical with considering the start of ability that must have of the students. (2) Develop and validate model cooperative learning (tutor coeval) with assisting of module that designed based on the cognitive grade and context of real world students and concept media map that assumed effective and efficient in developing of proofing ability. This model consists of module form and students activity sheet.

\section{The Review of Literature}

\subsection{Proofing in Structure Algebra Learning}

Algebra structure is commonly form of algebra system that taught in school grade (elementary school and senior high school), at school grade we know that number of algebra, function of algebra, matrix of algebra and so on viewed as a different thing, however actually got the same structure between algebra forms, that is, have group structure, ring and so on.

According to Bourbaki (in Made 2006), structures are one of the old abstract of mathematics and more simple that built by some axiom. As one of pure mathematics subject, the concepts of consist in algebra structure commonly is definition, axiom, and theorems that consist of systematically and hieracially and proofing process use deductive thinking. Prove/proofing is the main characteristic from mathematic activity, especially algebra structure, thus proofing must be the key component of learning process. Proofing in mathematics is one of the processes of taking conclusion from mathematics problem that the process done with deduction thinking.

\subsection{Media of Concept Map in Improving the Proofing Ability Algebra Structure}

As we explain above that structure of algebra is one of pure mathematics subject or abstract where the concepts consist inside at commonly are definition, axiom, and theorems that consist of hieracially mean that the concepts in algebra structure consist of concepts and also former facts and also the use of continually for explaining to explain the concepts are more abstract. The highest concepts built from the below concept.

Thus, the learning of concepts at algebra structure mainly including with proofing will be more direct if the students first arrange the concepts will be learnt from the common until the more special. Thus it will be happened meaningful learning so in cognitive structure the students must be any relevant concept, if there is no so that the new information already learnt memorizing. Therefore in learning process needed media of concept map? According to the statements of Novak (1985), it was said that the process of meaningful learning can happen if it done with assisting media of concept map. For example of concept map about Isomorph group concept (Figure 1).

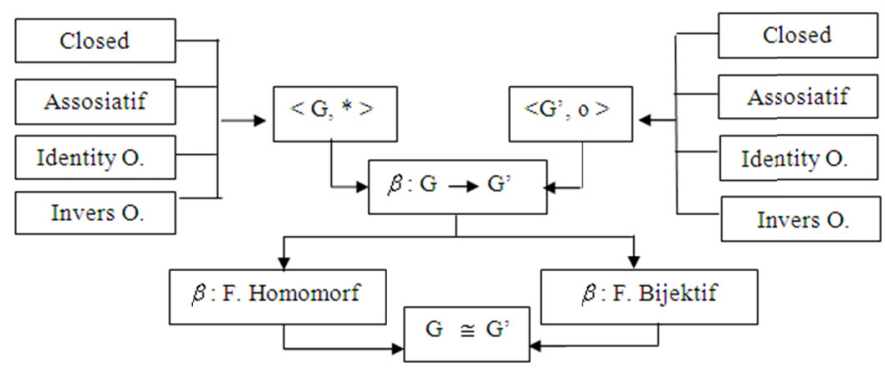

Fiture 1. Concept map about concept of Isomorf group 


\subsection{Cooperative Approach with Benefit of the Colleague's' Tutor Role}

In process teaching learning beside the benefit of concept media map need to be created learning environment that possible to the students to be positive interaction in constructing the algebra structure concepts. It means that will be done by cooperative learning with assisting colleagues tutor. Roger and Jhonson (Lie, 2004) stated that five elements of cooperative learning, that are: (1) Positive mutual dependence; (2) Individual responsibility; (3) Face to face; (4) Communication between group; (4) Communication between group; (5) Process of evaluation group. This thing indicates that the cooperative learning is very possible to increase student's ability together. Above statements is supported by Arends opinion (1997) stated that cooperative learning can be luckily between students with low achievement and students with high achievement that work together in academic assignment, the students with higher ability can be a colleague's tutor from the students have low ability. It indicates need to pay attention social environment that possible to the students to be positive interaction in constructing mathematics concepts. According to Vygotsky (Suharta, 2004; Suparno 1997), construction that pay attention to this social environment called with social constructivism, it basically from the view of knowledge statements can be formed either individual or social, so that the learning group can be developed.

There are two important concepts in Vygotsky theory (Slavin, 1997, Suharta, 2004) that is Zone of Proximal Development and Scaffolding. According to (in http://valmband.multiply.com) that is: Zone of Proximal Development is a gap between actual development and potential development, with another word is a child can do something without adult's assisting and is a child can do with directing adult or work together with colleague's friend. Though Scaffolding according to Prayudi (in http://prayudi.wordpress.com) is giving to a child big amount for beginning learning steps and then to decrease the assisting and giving a chance to the children taking away the responsibility that so big soon after he can do himself.

According to Myrick and Bowman (1981) stated that colleague's tutor is an individual that still school that use the concept and skill to help another students, not a teacher/concealer. Though Erney (1984), colleagues tutor are an individual that take care about another people and may talk with them about their feeling and viewing, not giving advice and finishing another people problem.

It can be concluded that colleagues tutor aim to help to build Self-development, academic achievement and doing positive and health relationship. Colleague's tutor has characteristics: easy going, have communication skill, happy to give helping to another people, not giving advice, not teacher/concealer, and not people to finish the problem.

Besides having ability in above, the most important ability must be had by colleagues tutor are academic ability especially in algebra structure material so that the students that feeling difficult to be expected can solve the problems together. According to Branley (Tim MKPBM, 2001) there are three basic models in doing learning with colleagues tutor, that are (1) Student to student, (2) Group to tutor, (3) Student to student, with spreading from three models as Figure 2.

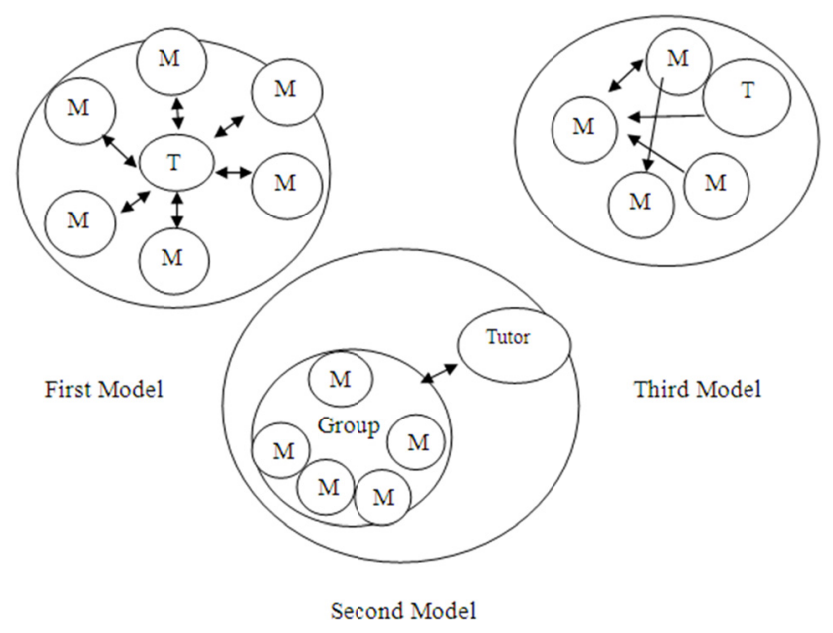

Figure 2. Learning model with colleagues tutor 


\subsection{The Benefit of Module in Learning}

Beside it needed the condition of environment in the classroom, learning sources or module is a factor that is not important, because it is still less the book of algebra structure in Indonesian language. It relates to difference of characteristic of students, like brain, skill, ability to study, and etc. For doing that it needed rule so that all students can achieve and understand learning material based on the properly time, for example per one semester. According to Tjipto Utomo (1990) the aim above can be achieved if the system of module can be done, they are with distributing learning material in each of material including one or some topics. According to Tjipto Utomo(1990) the system of module learning have characteristics, they are (1) the statement of learning target (2) the knowledge consist of in one frame that seen relationship and order in its part (3) the participation of student is active (4) the evaluation based on knowledge.

The target of learning is useful in arranging the module to direct target achievement and as one consideration for the students. Even though for the students can describe orderly the result that can be expected from their self, to do that the target must be said clearly and briefly in every module. When between one module with another so that it is said clearly, and the order of presenting the important parts can be paid attention in arranging the module, beside its elements for each learning target must be arranged according the knowledge degree.

In learning system the student's module arrange their self-module, do they choose to follow the lecturing or learning from module is only enough. So their self can be active, because without their active they will not finish their program. Beside their activeness in classroom discussion, also the students are expected can be more active in their self-activities. It means that, the students directed can be summary the material that will be explained at group discussion or classroom discussion. However the participation actively for a student not only guarantee that is learning, but also he is in willing to be possible to create the learning result is better.

Based on the characteristic for subject material algebra structure that organize hieracially so that the determination of frame learning material be done with degree frame, it means that the understanding of topic the material (evaluation based on understanding) that is one of requirements to get understand the topic of material. The way of this evaluation to make less the failure and guarantee that the students have understood content of chapter before they continue to next chapter.

\section{Research Method}

\subsection{Place and Time of the Research}

This research was done in mathematics and mathematics education program in Medan State University and Quality University in North Sumatra province. The time of the research was planned form March 2014 until December 2016.

\subsection{Research Approach}

This research was done by using the method of developmental research. According to Van den Akker (1999) called as formative research where the activities done in cyclic process and aim to optimize the quality for implementing product at the certain situation. This research done in three (3) steps, three steps can be drawn in Figure 3.

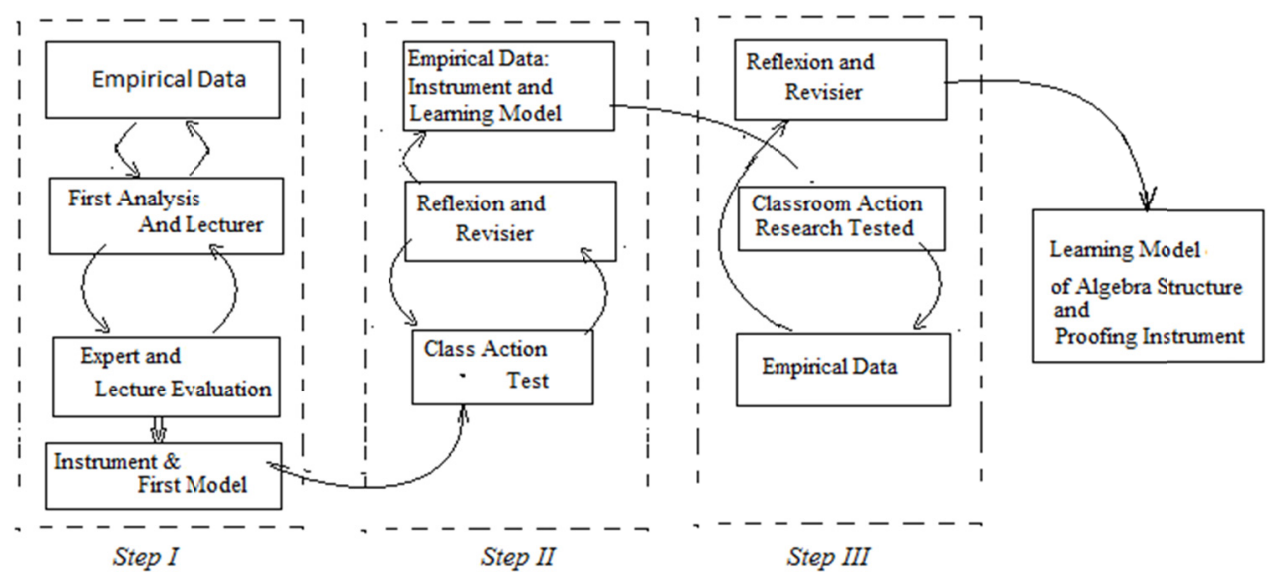

Figure 3. Steps and activities in developmental research 
The first step of this research is called front-end analysis aim to analyze empirical data to determine proofing ability and positive behavior on algebra structure that must be had for the students with considering the used of curriculum. This activity was followed with developing learning model algebra structure by using cooperative approach, concept media map, and module that arrange based on theory. Through justification, analyze and evaluation from mathematics experts and mathematics education and competence lecturers so that the first learning model (module) algebra structure. The first learning model with cooperative approach, assisting concept media map, module is one of the part have been developed by the researcher (Saragih, 2000; Syafari, 2003; Muliono and Syafari, 2009). The first activity was done for 8 months in this research.

\subsection{Research Systematical}

The ability of proofing that is the process of algebra structure learning still becomes the serious problem. It causes that the vision and objective of the algebra structure learning is not suitable with it is expected. There are some aspects that to be the cause factor from ability proofing problem, they are lecturing aspect, student, method/approach, algebra structure material, media and medium. The highlight of this problem in this research can be visualized like in the fishbone diagram Figure 4.

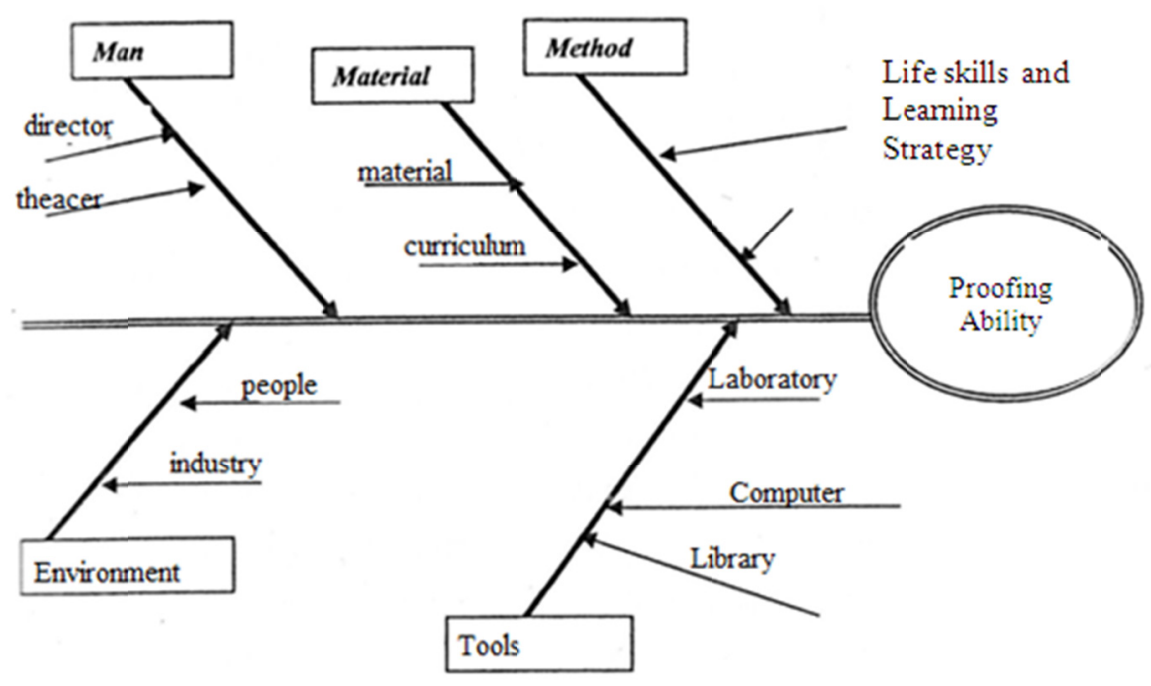

Figure 4. Diagram of fishbone research

On algebra structure material aspect will be tested the suitable requirement material concept, the suitable concept with cognitive degree of the students, the suitable concept with real life context with the students to formulate the proofing ability characteristics. Even though from method aspect or approach will be tested about ability lecturer in designing and developing the module (learning material) that suitable with the cognitive degree from the students, the suitable concept with context real life from the students with cooperative learning model. Even though from student aspect will be examined about increasing proofing ability and positive behavior the student on algebra structure material and learning model as impact from learning process. Furthermore from equipment aspect will be tested with supporting visual media and concept media map, library, lab, and environment in doing learning process. Even though from environment aspect will be tested general society commonly and supported from the university as supplying informant and human resources in creating the increasing in better education.

\section{The Result of the Research and Discussion}

The result that got of this research, they are: the formulation of proofing ability that include in Algebra Structure and the book of lecturer handing (lecturing unity schedule, lecturing contract, lesson plan), the instrument of proofing ability. It got seven learning activities, they are: learning activity 1 group mediation, learning activity 2 biner operation and group, learning activity 3 subgroup and skill group, learning activity 4 mutation, learning activity 5 orbits, cycles, and alternating group, learning activity 6, subgroup normal and factor group, learning activity 7 homomorphism, isomorphism and out directly timing and from every learning activity get 4 test so that all of getting 28 formulation the proofing ability from the resulted module. Distributing learning activity and 
formulate proofing ability have been said valid by validator and the result of try out in the field pointed the same result that is all the tests have validity and reliability with high category.

The above result pointed that either the good module or proofing ability tests exactly to measure what should be measured based on the taught material. Thus also with reliability test degree that high so that it pointed that either learning equipment's or proofing ability test will produce the same result (ajeg) when it done repetitively. It is supported by opinion of Arikunto (2013) that stated that a valid test and reliability indicate consistent and ajeg from its test, furthermore it said that a test has measured what should be measured, and it will produce the same that ajeg though it done repetitively. Beside that it got some inventions in designing the module and proofing process, they are:

1) In learning activity between group, many students that difficulty in using implication concept (if.....so...). Students do not understand the use of correct score from implication concept and part association concept. For example: problem if $\mathrm{A} \subseteq \mathrm{B}$ so $\mathrm{B}^{\mathrm{C}} \subseteq \mathrm{A}^{\mathrm{C}}$. Almost of the students are not able to prove the above problem. They still use the concept $\mathrm{B}^{\mathrm{C}} \subseteq \mathrm{A}^{\mathrm{C}}$ however the concept will be proved. However after he given including direction with new implication concept some students can understand the above problem.

2) In equivalent relation concept that is: if $f$ is an equivalent relation association at $\mathrm{H}$ association $\mathrm{S}$ and $\mathrm{a} \in \mathrm{S}$ so [ a ] $=\{\mathrm{x} \in \mathrm{S} \mid(\mathrm{a}, \mathrm{x}) \in f\}$ called equivalent class that include a. Most of the student felt difficulty in determining grouping from equivalent class that include a. When it asked who is group from [a\}? Most of the student are not able to answer, however when the concept included by real life context, for example $\mathrm{S}$ association of the students learn algebra structure subject and furthermore asked is the possible group [a] the people in the outside? They are able to answer from [a] is member from S. Furthermore the next questions how is member S? Finally they realized and most of the student are able to answer correctly.

3) The students still difficulty in understanding on concept Center from group $G$ written $Z(G)=\{a \in G \mid a x=$ $\mathrm{x} a, \forall \mathrm{x} \in \mathrm{G}\}$. The symbolization from Center concept still very difficult from the student, they do not understand who is member of $Z(G)$. However when the lecturer take the concept in daily life, for example association of $G$ student is following the algebra structure lecturing, then the question who is member of $\mathrm{Z}(\mathrm{G})$, there are students do not answer member of $\mathrm{G}$, then the next question continued how is member of $\mathrm{G}$ ? Almost of all students cannot answer, finally with some helping from given the student cannot answer.

4) Concept the subgroup below: a subset $\mathrm{H}$ that is not empty of group $\langle\mathrm{G}, *\rangle$ si subgroup of $\mathrm{G}$ if and if only:

a. $\forall \mathrm{a}, \mathrm{b} \in \mathrm{H}$ so $\mathrm{a} * \mathrm{~b} \in \mathrm{H}$ ( First Axiom of group definition )

b. $\forall \mathrm{a} \in \mathrm{H}$ so $\mathrm{a}^{-1} \in \mathrm{H}$ ( fourth Axiom of group definition)

Many students felt misconception at the above concept, the students realize that the concept is implication or implication two ways, however when it is in processing proofing concept the students are not able to use two kinds. However after they given explanation that two kinds are close kinds and invers kinds (two of four kind group) already can start the proofing process.

5) It the same thing with applying subgroup concept: association $H$ that part finite and not empty from group G. $\mathrm{H}$ subgroup of $\mathrm{G}$ if $\mathrm{H}$ contain close kind. Part of the students are not able use the concept subgroup $\mathrm{H}$ subgroup, when it fulfilled $\mathrm{H}$ association parts are finite of group $\mathrm{G}$, they do not realize that with using Cayley table and fulfill close kind have been enough to conclude that $\mathrm{H}$ of subgroup $\mathrm{G}$.

6) Understand the Kernel concept or core of $\rho$, with $\rho$ is a homomorphism of $G$ to $G^{\bullet}$ that is $I(\rho)$ definite with $\mathrm{I}(\rho)=\left\{x \in G \mid \rho(x)=e^{\bullet}\right\}, e^{\bullet}$ is neutral element of $G^{\bullet}$, is concept that still difficult to understand by most of the students. However after they drawn a diagram like in the below and some questions they can understand members of association $I(\rho)=\{a, e\}$

7) Cycle concept that is: $\rho$ is mutation of association A, said Cycle if $\rho$ has many 1 orbit that contain more than 1 element. Many students that felt difficulty in understanding Cycle concept, however after they given some examples and not example the student have already understood. Furthermore they given assignment for making mutation example that is Cycle and not Cycle.

8) Understand and apply concept subgroup of a theorem that sound as: $\mathrm{H}$ is part association that finite and not empty of group G. H subgroup of G if $\mathrm{H}$ fulfilled close characteristic. Most of the students are not able to understand and apply the concept in processing problem finishing, for example: pay attention group $Z_{8}=\{0,1,2,3,4,5,6,7\}$. With Cayley table can be observed associations part of $H_{1}=\{0,4\}$ and $H_{2}=\{0,2,4,6\}$ is subgroup of $\mathrm{Z}_{8}$. It is not a little students that prove with showing four characteristics of group at association $\mathrm{H}_{1}=\{0,4\}$ and $\mathrm{H}_{2}=\{0,2,4,6\}$ 
Some cases in the above showed that proofing ability that is the main characteristic of mathematic activity for graduate students (S-1) mathematic education was still big problem. So many students still felt difficulty in understanding algebra concepts that are abstract, so that the lecturer need to give an assisting with including the concept in the real context that include in daily life, it designed in forming learning module. Beside it interacted between students and students and between students and lecturer gave positive contribution in doing maximal students' understanding, so that it needs to pay attention. In that process proved many students that assisted in understanding the concept. It is suitable with Arends's opinion (1997) that said that learning cooperatively can be benefit between students with low achievement and students with high achievement that work together in academic assignment, the student can be higher can be colleague's tutor of student's low ability. The benefit of learning cooperatively also supported by the result of research Saragih (2000) that the result that cooperative learning approach in learning algebra structure can help students' understanding either low group or high group.

The including between one concept and another concept also become to pay attention, many students that felt difficulty in understanding concept that abstract and more commonly, for example mutation concept that consist of bijective function, group concept with subgroup, center, and centralizer, kernel or core, isomorphism, and so on. In understanding the concept that more abstract will be easy if the students can understand the simpler concept, all of this need to include and in understanding to the concepts needed concept media map. It is supported by Novak's opinion Novak (1985) that stated so that meaningful learning in cognitive structure students must be any relevant concepts, if there is no new information can be taught memorizing, it can be done with helping concept media map. The benefit of concept media map and students interaction in learning also supported by the research Syafari and Saragih $(2001,2003)$ that stated that happened minimization and revision misconception students in learning transformation geometry and real analyze through remedial learning by using concept media map and colleagues tutor.

\section{Conclusion and Suggestion}

\subsection{Conclusion}

This research concluded they are:

1) From the try out validity tested got learning module in algebra structure subject that consist of seven learning activities and twenty eight formulate the proofing ability that said that valid and have high reliability.

2) Learning model with cooperative approach assisting concept media map by using module can increase the proofing ability.

\subsection{Suggestion}

This research suggested they are:

1) To the lecturer of education mathematic major though another major expected can design learning module in every own subject.

2) To the lecturer mathematic education major though another major expected can design and apply learning model with cooperative approach expected can design and apply learning model with cooperative approach with assisting concept media map in every own subject.

3) To the lecturer mathematic education especially in algebra structure subject though another subject that have analyzed characteristics expected can design the instrument of proofing ability.

\section{Acknowledgments}

Writer realized that so many participant that included to help to finish this research. Therefore at this chance the writer like to deepest thank to the DIKTI that have given fund through grant competition research, the lecturer of mathematics education major and all staffs in Medan State University.

\section{References}

Arikunto, S. (2013), Basics of Education Evaluation (2nd ed.). Jakarta: Bumi Aksara

Asikin, M. (2002). The Improving of Effectiveness Proving Learning on Algebra Structure through Learning Model of Conceptual Changing with CLS (Cooperative Learning Strategies). Paper on Seminar Mathematic National in FMIPA UMN. Malang.

Dubinsky, E., \& Leron, U. (1994). Learning Abstract Algebra with ISETL. New York: Springer-Verlag. https://doi.org/10.1007/978-1-4612-2620-8 
Erney, T. (1984). Caring and Sharing: Becoming a Friendly Helper: A Handbook for Student Facilitators. Educ. Media Corp. Minnesota.

Findel, B. R. (2001). Learning and Understanding in Abstract Algebra. Disertasi. New Hampshire: not published.

Fraleigh, J. B. (1989). A First Course In Abstract Algebra (4th ed.). University of Rhode Island. New York.Addison-Wesley Publishing Company Inc.

Galian, J. A. (1998). Contemporary Abstract Algebra (4th ed.). University of Minnesota, New York, Boston.

Hanna, G., \& Jahnke, N. (1996). Proof and Proving. In A. J. Bishop et al. (Eds.), International Handbook of Mathematics Education. Dordrecht: Kluwer Academic Publishers. https://doi.org/10.1007/978-94-009-1465-0_27

Herstein, I. N. (1975). Topics in Algebra. New York: John Wiley \& Sons.

Kromodiharjo, K. (1988). Material of Topic Algebra Structure. Publisher Karunika Jakarta UT.

Lee, P. Y. (2004). What Do We Do with School Geometry? Paper on Conference on Recent Progress in Mathematics Education (CRPME 2004), 6-9 September 2004. ITB Bandung.

Made, A. I. (2006). Improving the Students Ability Proving in Algebra Abstract through Learning based on APOS Theory (Unpublished dissertation, University of Indonesia Education. Bandung).

Mulyono, \& Syafari (2009). Improving proving ability and students' interaction in algebra structure learning through assisting concept media map and colleagues tutor. Research report. Unimed. Medan.

Myrick, R. D., \& Bowman. (1981). Becoming a friendly Helper: A Handbook for Student Facilitators. Educ. Media Corp, Minnesota.

Novak, J. D., \& Gowin, D. B. (1985). Learning How to Learn. Cambridge: Cambridge University Press.

Regis, A., \& Albertazi, P. G. (1996). Concept Maps In Chemistry Education. J. of Chemical Education, 73, 1084-1088. https://doi.org/10.1021/ed073p1084

Saragih, S. (2000). Cooperative Learning Approach in Learning Algebra Structure by Using Concept Map. Research Report IKIP Medan, Medan.

Saragih, S. (2005). Mathematics Learning with Concept Map, Medium Equipment, and Group Discussion. Journal of Education State University of Yogyakarta, 33(1), 53-62.

Syafari, \& Saragih, S. (2001). The Efforts of Minimization Students Misconception in Transformation Geometry Learning through Remedial Learning by Using Concept map media. Research Report IKIP Medan, Medan.

Syafari, \& Saragih. (2003). The Efforts to Improve Students' Misconception in Real Analyze Learning through Remedial Learning with Assisting Concept Map Media and colleagues Tutor. Research report, Unimed. Medan

Team of MKPBM. (2001). Strategy of Contemporary Mathematic Learning. JICA UPI. Bandung.

Team of Task Force (2007). Self-Evaluation on Mathematic Education Study Program. Paper presented on Monev Mathematics FMIPA UNIMED.

\section{Copyrights}

Copyright for this article is retained by the author(s), with first publication rights granted to the journal.

This is an open-access article distributed under the terms and conditions of the Creative Commons Attribution license (http://creativecommons.org/licenses/by/4.0/). 